Acta Universitatis Wratislaviensis No 4053

Studia Linguistica XL Wrocław 2021

https://doi.org/10.19195/0137-1169.40.9

RITA WŁODARCZYK

ORCID: 0000-0002-4751-1946

Uniwersytet Wrocławski, Polska

KACPER KOCUR

ORCID: 0000-0002-2637-9413

Uniwersytet Wrocławski, Polska

\title{
Różnorodność języka hiszpańskiego. Badania porównawcze na materiale języka hiszpańskiego i jego odmian używanych w krajach Ameryki Łacińskiej
}

Od czasów odkrycia Ameryki przez Krzysztofa Kolumba, czyli od końca XV wieku, język hiszpański (w różnych odmianach) stopniowo stawał się językiem urzędowym podbijanych przez hiszpańskich kolonizatorów krajów od Meksyku, poprzez Karaiby, na Chile kończąc. Kontakt języka hiszpańskiego z językami rdzennych mieszkańców Ameryki Łacińskiej doprowadził do powstania latynoamerykańskiej odmiany języka hiszpańskiego, która w każdym z krajów różni się od siebie pod wieloma względami.

\section{Klasyfikacja genetyczna języka hiszpańskiego}

Język hiszpański, zwany również kastylijskim ${ }^{1}$, zgodnie z współczesną klasyfikacją genetyczną zalicza się do grupy języków zachodnioromańskich, występujących w obrębie podrodziny romańskiej języków indoeuropejskich. Rozpowszechnianie się hiszpańszczyzny na świecie związane było z rozwojem imperium hiszpańskie-

1 Język hiszpański przez swoich natywnych użytkowników zarówno w Europie, jak i w Ameryce Łacińskiej nazywany jest wymiennie español lub castellano. Druga z nazw odnosi się do kastylijskich korzeni hiszpańszczyzny. 
go i prowadzoną przez nie ekspansją kolonialną w XV i XVI wieku, na skutek której kultura hiszpańska wyparła na terenach współczesnej Ameryki Łacińskiej² cywilizację Indian. Z uwagi na różnorodność kulturową użytkowników omawianego języka, a także rozległy obszar geograficzny, na którym jest używany, kastylijski posiada rozmaite odmiany, wśród których można obserwować różnice na poziomach fonetycznym, gramatycznym i leksykalnym. Sama Hiszpania jest krajem wielonarodowym i wielojęzykowym, a artykuł 3 Konstytucji Hiszpanii z 27 grudnia 1978 roku stanowi co następuje:

1. Kastylijski jest hiszpańskim urzędowym językiem państwa. Wszyscy Hiszpanie mają obowiązek go znać i prawo posługiwać się nim.

2. Pozostałe języki hiszpańskie są również językami urzędowymi w odpowiednich wspólnotach autonomicznych, zgodnie z ich statutami.

3. Bogactwo różnych odmian językowych Hiszpanii jest dziedzictwem kulturowym, które jest przedmiotem szczególnego poszanowania i szczególnej ochrony ${ }^{3}$.

Do respektowanych przez Konstytucję ${ }^{4}$ pozostałych języków urzędowych zaliczają się: aragoński w Aragonii, aranejski w Dolinie Aran, asturyjski w Asturii, baskijski w Baskonii i Nawarze, estremadurski w Estremadurze, galicyjski w Galicji, Eo Navii, El Bierzo i Dolinie Jalamy, kantabryjski w Kantabrii, kataloński w Katalonii, La Franji i na Balearach, leoński w Leonie, portugalski w Olivenzie oraz walencki w Walencji i El Carche. Poza Hiszpanią, język kastylijski jest językiem urzędowym dziewiętnastu państw Ameryki Łacińskiej ${ }^{5}$. Według badań Instytutu Cervantesa w 2020 roku językiem hiszpańskim jako ojczystym posługiwało się 489 milionów osób, a łączną liczbę jego użytkowników oszacowano na 585 milionów $^{6}$, co plasuje go na drugim miejscu na świecie (po języku chińskim mandaryńskim) pod względem liczby natywnych użytkowników. Ponadto hiszpański jest trzecim najpowszechniej używanym w komunikacji językiem na świecie, po językach chińskim, mandaryńskim i angielskim.

Jacek Perlin w przedmowie do „Polityki językowej a języka mniejszości” José Maríi Tortosy pisze, że podstawowym problemem badacza pragnącego usystematyzować języki świata jest ustalenie, czy w konkretnym przypadku ma do czy-

${ }^{2}$ W niniejszej pracy posługujemy się pojęciami „Ameryka Łacińska” oraz „Iberoameryka”, odnoszącymi się do hiszpańskojęzycznych krajów Ameryki Środkowej i Południowej.

3 Zob. https://biblioteka.sejm.gov.pl/wp-content/uploads/2015/10/Hiszpania_pol_300612.pdf (dostęp: 27.01.2021).

4 Zob.https://www.senado.es/web/wcm/idc/groups/public/@cta_rrdc/documents/document/mdaw/ mdiz/ edisp/lenguas_oficiales_ccaa.pdf (dostęp: 26.04.2021).

5 Argentyna, Boliwia, Chile, Dominikana, Ekwador, Guatemala, Gwinea, Honduras, Kolumbia, Kostaryka, Kuba, Meksyk, Nikaragua, Panama, Paragwaj, Peru, Urugwaj i Wenezuela.

${ }^{6}$ Zob.https://cvc.cervantes.es/lengua/espanol_lengua_viva/pdf/espanol_lengua_viva_2020.pdf(dostęp: 27.01.2021). 
nienia $\mathrm{z}$ dialektami lub odmianami jednego języka, czy też z różnymi językami: „Nie wiadomo też, które różnice są bardziej, a które mniej relewantne: fonetyczne, morfologiczne, składniowe czy leksykalne. Zdolność wzajemnego porozumiewania się jest w praktyce trudna do zastosowania, zależy od wielu czynników, takich jak temat rozmowy, szybkość i czystość artykulacji, dobór słownictwa, inteligencja rozmówców. Wszystko to razem powoduje, iż wszelkie podziały na języki i dialekty oparte zostały wyłącznie na kryteriach nielingwistycznych, mianowicie socjologicznych, a ściśle: socjologiczno-polityczno-kulturowo-historycznych" (Tortosa 1986:7). Tortosa w swoich badaniach językowych dochodzi do wniosku, że jedynym sensownym kryterium wydaje się poczucie przynależności językowej użytkowników. Użytkownicy języka nie zawsze są zgodni co do tego, czy mówią odrębnym językiem, czy dialektem. Z punktu widzenia socjolingwistycznego wszystkie żywe, współcześnie używane języki można podzielić na znormalizowane i nieznormalizowane. „Znormalizowana wersja języka nazywana jest zwykle, niezbyt precyzyjnie, językiem literackim, kulturalnym lub ogólnonarodowym. [...] Nieznormalizowane warianty języków noszą nazwy gwar, dialektów, narzeczy, żargonów" (Tortosa 1986:8-9).

\section{Korzenie hiszpańszczyzny i pojęcie puryzmu - próba analizy etnolingwistycznej}

Z uwagi na heterogeniczność języka hiszpańskiego, istotne jest poznanie wpływów nań innych języków. Jerzy Szałek (2013:117) za Concepción Otaolą Olano wymienia trzy źródła zasobu leksykalnego języka hiszpańskiego: wyrazy pochodzące z łaciny ludowej (ok. 23\%), zapożyczenia leksykalne z języków arabskiego, greckiego i łacińskiego, a także pozostałych języków romańskich (ok. 41\%) oraz nowopowstałe wyrazy (ok. 35\%). Mimo że zjawisko przenikania się języków nie ominęło mowy hiszpańskiej, na przestrzeni wieków podnoszono argumenty o konieczności zachowania etymologicznej czystości zasobu leksykalnego, co związane było między innymi ze zjawiskiem ${ }^{7}$ kastycyzmu (Magis 1986:481). Ángel Rosenblat (1970:483), zajmując się różnicami występującymi w obrębie języka hiszpańskiego, stwierdził, że mówienie o puryzmie językowym w takim rozumieniu nie tylko jest błędne, ale także nosi znamiona szowinizmu: ,[...] qué quiere decir pureza castellana? El castellano es un idioma evolucionado que adoptó elementos ibéricos, visigóticos, árabes, griegos, franceses, italianos, ingleses y hasta indígenas de América. Cómo se puede hablar de pureza castellana, o en qué momento podemos fijar el castellano y pretender que toda nueva aportación constituye una imputeza nociva? La llamada pureza es en última instancia una espe-

${ }^{7}$ Kastycyzm to postawa ideologiczna, która pojawiła się w Hiszpanii w XVII wieku. Zakładała między innymi uwolnienie się hiszpańskiej kultury i języka od wpływów zagranicznych. 
cie de proteccionismo aduanero, de chauvinismo lingüístico, limitado, mezquino y empobrecedor, como todo chauvinismo" 8 .

\section{Zjawisko voseo}

Pod względem gramatyczno-socjolingwistycznym voseo stanowi jedną z najbardziej wyraźnych różnic występujących między europejską a amerykańską odmianą języka kastylijskiego. Występuje ono w różnych wariantach w Argentynie, Urugwaju, Paragwaju, części Boliwii, w wenezuelskim stanie Zulia, w kolumbijskiej Antioquii oraz całej Ameryce Środkowej. W praktyce voseo polega na zamianie zaimka drugiej osoby liczby pojedynczej tú na jego dawny odpowiednik vos. Chociaż obie formy bywają używane w mowie i w piśmie, częściej spotyka się zaimek vos. Ponadto w liczbie pojedynczej zjawisko voseo powoduje wprowadzenie specyficznej odmiany dla zaimka w drugiej osobie, co skutkuje zmianą akcentowania lub pojawieniem się zupełnie nowych form. Odnośnie do liczby mnogiej, zaimek vosotros zasadniczo nie jest używany - został zastąpiony przez trzecią osobę liczby mnogiej: ustedes. Zastępowanie w liczbie mnogiej vosotros przez ustedes jest cechą charakteryzującą wszystkie warianty latynoamerykańskiej odmiany języka hiszpańskiego (Guillermo-Sajdak 2013:120).

\section{Dialekt rioplatense}

Odmiany języka hiszpańskiego w Argentynie i Urugwaju wykształciły rozmaite zmiany w leksyce, fonetyce i gramatyce. W zależności od regionu geograficznego i pochodzenia społecznego użytkowników języka, wzmiankuje się dialekt rioplatense, hiszpański porteño w odmianie oficjalnej oraz potocznej - lunfardo (Guillermo-Sajdak 2013:120). Istnienie tego specyficznego, opartego na języku włoskim dialektu tłumaczone jest przewagą w społeczeństwie argentyńskim emigrantów włoskich (45\%) nad hiszpańskimi (33\%) (Sarramone 1999:12-13). Jorge Luis Borges w humorystyczny sposób skomentował to zjawisko: „A veces pienso que no soy argentino, ya que no tengo sangre ni apellido italianos"9 (zob. Kaganiec-Kamieńska 2012:57). Wymowa dialektu rioplatense przypomina akcentem

8 ,[...] kto chce mówić o hiszpańskiej czystości językowej? Język hiszpański to wyewoluowana łacina, która przyjęła elementy iberyjskie, wizygockie, arabskie, greckie, francuskie, włoskie, angielskie i nawet indiańskie. Jak można mówić o hiszpańskiej czystości językowej lub w którym momencie możemy ustalić ostateczny język hiszpański i udawać, że każde nowe zapożyczenie stanowi szkodliwą nieczystość? Tak zwana czystość językowa to ostatecznie rodzaj ochrony celnej, szowinizmu językowego, ograniczonego, podłego i zubożającego, jak każdy szowinizm" (tłum. własne).

9 „Czasami myślę, że nie jestem Argentyńczykiem, bo nie mam włoskiej krwi ani nazwiska” (tłum. własne). 
i intonacją język włoski. Jest to tak zwana intonacja wznosząco-opadająca, która charakteryzuje się rosnącym konturem na początku wypowiedzi oraz jego spadkiem na ostatniej sylabie.

\section{Materiał badawczy i metodologia}

Prowadzone przez nas badania zakładały wskazanie różnic w leksyce i konstrukcjach gramatycznych występujących pomiędzy odmianami języka hiszpańskiego w Hiszpanii i krajach Ameryki Łacińskiej. W tym celu zorganizowaliśmy trzyosobowe grupy respondentów z sześciu krajów: Argentyny, Chile, Hiszpanii, Kolumbii, Meksyku oraz Wenezueli. Chcąc uzyskać jak najbardziej miarodajny materiał, zdecydowaliśmy się na dobór państw ze względu na ich położenie geograficzne, a także przewidywane wpływy innych języków, wynikające z procesów migracyjnych. Respondenci biorący udział w badaniu to osoby pomiędzy dwudziestym a trzydziestym rokiem życia, studiujące lub aktywne zawodowo, używające na co dzień języka hiszpańskiego:

1. Argentynę reprezentowali dwie kobiety i jeden mężczyzna, zamieszkujący północną i wschodnią część kraju; wszyscy wywodzili się z rodzin pochodzenia włoskiego.

2. Chile reprezentowało trzech mężczyzn, w tym dwóch zamieszkujących centralny region Metropolitana i jeden pochodzący z północnej Ariny y Parinacoty; jeden $\mathrm{z}$ respondentów był metysem ${ }^{10}$, dwóch pochodziło $\mathrm{z}$ rodzin europejskich emigrantów.

3. Hiszpanię reprezentowali dwie kobiety i jeden mężczyzna, wszyscy byli mieszkańcami Madrytu, spośród których jedna osoba urodziła się i wychowała w Andaluzji.

4. Kolumbię reprezentowało dwóch mężczyzn i jedna kobieta, w tym dwie osoby pochodzące z południowo-zachodniego departamentu Huila i jedna wywodząca się z graniczącego z Brazylią departamentu Vaupés. Wszyscy respondenci to osoby pochodzenia metyskiego.

5. Meksyk reprezentowały trzy kobiety, zamieszkujące środkowozachodni stan Jalisco; jedna z nich deklarowała pochodzenie indiańskie, kolejna metyskie, trzecia urodziła się w Hiszpanii, a wychowała w Guadalajarze.

6. Wenezuelę reprezentowało dwóch mężczyzn i jedna kobieta. Mężczyźni byli mieszkańcami Dystryktu Stołecznego, kobieta pochodziła z zachodniej prowincji Táchira.

Przygotowaliśmy sześć wypowiedzi, których tematyka dotyczyła żywności i życia codziennego. Dzięki wykorzystaniu jednostek leksykalnych związanych

10 Określenie metys (hiszp. mestizo), oznaczające osobę mieszanego pochodzenia europejskoindiańskiego, na ogół nie jest uznawane przez Latynosów za obraźliwe. Bywa jednak używane w charakterze pejoratywnym (jako 'mieszaniec') i wówczas jest niepożądane. 
z uniwersalnymi, powszednimi praktykami, udało nam się podjąć próbę zbudowania obrazu języka codziennego w poszczególnych krajach, z zaakcentowaniem różnic na poziomie leksykalnym i gramatycznym. Respondenci otrzymali przygotowane frazy w języku angielskim. Zadaniem badanych było przetłumaczenie wypowiedzi na język hiszpański zgodnie z jego odmianą używaną przez nich na co dzień.

1. Thanks to using this pan, you guys can make an excellent popcorn. ('Dzięki użyciu tej patelni, możecie zrobić doskonały popcorn').

2. It's good to keep onions and lemons together in a fridge. ('Dobrze jest trzymać cebule i cytryny razem w lodówce').

3. I'm going to make a cake with pineapple, I have to buy more flour. ('Zamierzam zrobić ciasto $\mathrm{z}$ ananasem, muszę kupić więcej mąki').

4. If I don't catch this bus, I won't be on time at the grocery store and I will not be able to prepare the dinner.

('Jeżeli nie złapię tego autobusu, nie będę na czas w sklepie i nie będę mógł przyrządzić kolacji').

5. Peaches, bananas and grapes cost a lot.

('Brzoskwinie, banany i winogrona kosztują dużo').

6. Do not touch this pot! It's hot and the soup is not ready yet.

('Nie dotykaj tego garnka! Jest gorący, a zupa nie jest jeszcze gotowa').

\section{Wyniki przeprowadzonego badania i ich analiza}

Pierwsze zdanie w każdym przypadku rozpoczyna się w ten sam sposób.

Argentyna

1. Gracias por utilizar esta paila, hacen un buen pochoclo.

2. Gracias por usar este sartén, hacen un buen pochoclo.

3. Gracias por usar este sartén, hacen un buen pororó.

Chile

1. Gracias por utilizar esta paila, ustedes hacen un muy buen maiz.

2. Gracias por utilizar este sartén, hacen unas buenas cabritas.

3. Gracias por usar este sartén, hacen buenas cabritas.

Hiszpania

1. Gracias por usar esta sartén, hacéis unas buenas palomitas.

2. Gracias por utilizar esta sartén, vosotros podéis preparar unas buenas rosetas.

3. Gracias por usar esta sartén, podéis preparar unas buenas rosetas. 
Kolumbia

1. Gracias por usar esta paila, ustedes hacen un excelente maíz pira.

2. Gracias por usar este sartén, ustedes pueden hacer muy buen maiz pira.

3. Gracias por usar la paila, ustedes pueden hacer un excelente popcorn.

Meksyk

1. Gracias por usar esta sartén, hacen un tremendo pop.

2. Gracias por utilizar esta sartén, hacen un excelente popcorn.

3. Gracias por usar esta sartén, ustedes hacen un tremendo popcorn.

Wenezuela

1. Gracias por utilizar este sartén, hacen unas buenas cotufas.

2. Gracias por usar este sartén, hacen un buen popcorn.

3. Gracias por usar este sartén, hacen unas cotufas perfectas.

Wyrażenie gracias por ('dzięki temu') jest powszechnie używane we wszystkich badanych krajach. Respondenci różnie tłumaczyli wyrażenie $u \dot{z} y w a c ́$ - zaobserwowaliśmy dwa czasowniki: usar i utilizar. Oba te wyrazy są synonimami i nie występują między nimi żadne różnice znaczeniowe. Mimo to czasownika usar używa się częściej w mowie potocznej, utilizar natomiast spotykany bywa w języku specjalistycznym. Badane przez nas osoby stosowały oba słowa zamiennie, niezależnie od kraju pochodzenia.

W przypadku słowa patelnia zaobserwowaliśmy natomiast różnice zarówno na poziomie gramatycznym, jak i leksykalnym. Okazało się, że leksem sartén w zależności od państwa występuje w innym rodzaju. Hiszpanie używają formy la sartén (esta sartén - 'ta/tej patelni'), wśród Latynosów dominuje rodzaj męski el sartén (este sartén). Wyjątek stanowili respondenci z Meksyku, gdzie również sartén reprezentuje żeński rodzaj gramatyczny. Należy podkreślić, że Stowarzyszenie Akademii Języka Hiszpańskiego (Asociación de Academias de la Lengua Espaňola) zaleca jednak formę la sartén (Real Academia Española 2014). Argentyńczycy, Chilijczycy i Kolumbijczycy myśląc o patelni, posługiwali się też leksemem paila. Jest to typ sprzętu kuchennego, kształtem i funkcjonalnością przypominający standardową patelnię, jednak większych rozmiarów i służący nie tylko do przyrządzania, ale i serwowania potraw. Mieszkańcy krajów, w których używane są paile, nazywają w ten sposób również podobne akcesoria. Co ciekawe, w Chile i Kolumbii leksem paila ma też konotacje negatywne i bywa używany jako określenie czegoś brzydkiego, niewłaściwego ${ }^{11}$.

W kwestii popcornu można zauważyć, że potrawa ta, w Polsce określana zapożyczeniem z języka angielskiego, w krajach hiszpańskojęzycznych występuje

11 Zob. https://cnnespanol.cnn.com/2019/07/12/diccionario-de-colombianismos-que-significanchino-pelado-napa-y-mermelada/ (dostęp: 25.01.2021). 
pod rozmaitymi nazwami. W samej Hiszpanii popularnymi terminami są rosetas ('różyczki') i palomitas ('gołąbki'), co ma nawiązywać do niewielkich rozmiarów i kształtu tej przekąski. Chilijczycy również wykorzystują skojarzenia animalne; używany przez nich leksem cabritas tłumaczy się dosłownie jako 'kózki'. W Argentynie najczęściej spotyka się termin pochoclo, będący połączeniem leksemów pop (zapożyczonego z języka angielskiego) i choclo, który lokalnie oznacza kolbę kukurydzy. W północnej i wschodniej części kraju, z których pochodzili nasi respondenci, używane jest też określenie pororó, wywodzące się z języka Avañe'ẽ mowy plemienia Guarani ${ }^{12}$. Meksykanie posługują się amerykańskim popcorn, podobnie jak Kolumbijczycy, u których określenie to jest używane zamiennie z maiz pira ('prażona kukurydza'). W Wenezueli natomiast dominuje określenie cotufas, którego etymologia nie jest jasna ${ }^{13}$, choć niewykluczone są wpływy arabskie, łacińskie, a nawet niemieckie ${ }^{14}$.

Najbardziej widoczną różnicą między europejską a latynoamerykańską odmianą języka hiszpańskiego na poziomie gramatycznym, jaką możemy zaobserwować w tym przykładzie, jest kwestia drugiej osoby liczby mnogiej. We wszystkich przykładach od respondentów pochodzących z Ameryki Łacińskiej użyto trzeciej osoby liczby mnogiej ustedes (w europejskim hiszpańskim używanej wyłącznie jako forma grzecznościowa - 'panowie, panie, państwo'), zastępującej hiszpański zaimek vosotros ('wy'). Jak można zauważyć, odmiana czasownika $h a-$ cer ('robić'), odbywa się z pominięciem obecnego w oryginalnym języku hiszpańskim sufiksu -áis/-éis na rzecz formantu -an/-en, charakterystycznego dla trzeciej osoby liczby mnogiej. Tendencja ta, związana z omówionym wcześniej zjawiskiem voseo, dotyczy zaimka vosotros (jak również zaimka vos, przymiotnika dzierżawczego vuestro i nieakcentowanego zaimka w funkcji dopełnienia os) i pojawiła się w samej Hiszpanii, a konkretnie na jej południowo-zachodnim wybrzeżu. Można było obserwować ją między innymi w miastach takich jak Cádiz, Huelva czy Sevilla, będących od wieków ważnymi ośrodkami handlowymi, co tłumaczy jej obecność w Ameryce Łacińskiej.

Drugie zdanie eksponuje przede wszystkim kolejne różnice w leksyce.

Argentyna

1. Es bueno tener cebollas y limones juntos en el frigorifico.

2. Es bueno tener cebollas y limones juntos en la heladera.

3. Es bueno tener cebollas y limones juntos en la heladera.

\footnotetext{
12 Guarani to plemię południowoamerykańskich Indian, zamieszkujących głownie Boliwię, Paragwaj i północno-wschodnie obszary Argentyny. Kilka słów wywodzących się z ich języka, weszło do powszechnego użytku w hiszpańszczyźnie, między innymi carpincho ('kapibara'), maracas ('marakasy' - popularny instrument perkusyjny) i yaguar ('jaguar').

13 Zob. https://www.academiacanarialengua.org/consultas/36/ (dostęp: 25.01.2021).

14 Zob. http://etimologias.dechile.net/?cotufa (dostęp: 25.01.2021).
} 
Chile

1. Es bueno mantener cebollas y limones todos juntos en el refrigerador.

2. Es bueno mantener cebollas y limones juntos en el refri.

3. Es bueno mantener cebollas y limones juntos en el rerfigerador.

Hiszpania

1. Es bueno mantener las cebollas y los limones juntos en la refrigeradora.

2. Es bueno mantener las cebollas y los limones juntos en el refrigerador.

3. Es bueno mantener cebollas y limones juntos en la refrigeradora.

Kolumbia

1. Es bueno tener cebollas y limones juntos en la nevera.

2. Es bueno tener las cebollas y los limones juntos en la nevera.

3. Es bueno tener cebollas y limones en la nevera.

Meksyk

1. Es bueno mantener juntos cebollas y limones en el refrigerador.

2. Es bueno mantener juntos cebollas y limones en la nevera.

3. Es bueno mantener cebollas y limones juntos en el refrigerador.

Wenezuela

1. Es bueno tener cebollas y limones juntos en la nevera.

2. Es bueno tener cebollas y limones juntos en la nevera.

3. Es bueno tener cebollas y limones juntos en la nevera.

Choć onions i lemons w każdym przypadku tłumaczone były tak samo, to w zależności od kraju obserwowaliśmy użycie czasownika tener ('mieć, trzymać') lub mantener ('utrzymywać, zachowywać'). Pierwszy z nich wykorzystywany był w Argentynie, Kolumbii i Wenezueli, w pozostałych krajach respondenci konsekwentnie tłumaczyli to keep jako mantener. Słownik Hiszpańskiej Akademii Królewskiej (2001) wskazuje, że mantener określa czynność trzymania czegoś w taki sposób, aby się nie przewróciło, co uzasadnia wykorzystanie tego czasownika w kontekście przechowywania żywności. Hiszpańskie słowo refrigeradora ('lodówka') ${ }^{15}$, wywodzące się od łacińskiego frigus ('zimno'), nie jest powszechnie używane przez mieszkańców Ameryki Łacińskiej, poza Chile, gdzie zaobserwowaliśmy również skróconą formę refri, należącą do mowy potocznej. W większości przypadków respondenci z Ameryki Łacińskiej posługiwali się leksemem nevera, wywodzącym się z łacińskiej nazwy nivaria, której etymologia z kolei

15 Obserwuje się również użycie tego rzeczownika w rodzaju męskim - el regrigerador. Słownik Hiszpańskiej Akademii Królewskiej zaleca jednak używanie rodzaju żeńskiego (Real Academia Española 2014). 
sięga słowa nivis ('śnieg'). Dawniej określano tak miejsce magazynowania śniegu służącego do konserwowania żywności. Zaadaptowanie go jako nazwę urządzenia służącego do przechowywania produktów żywnościowych jest więc logiczne i uzasadnione. W Argentynie dominują dwa określenia: frigorifico, pochodzące od łacińskiego frigorificus ('urządzenie wytwarzające zimno'), oraz heladera, oparte na leksemie helado ('lód').

Trzecia fraza była tłumaczona w podobny sposób.

Argentyna

1. Voy a hacer la tarta de ananá, y compraré más harina.

2. Voy a hacer la tarta de ananá, y tengo que comprar más harina.

3. Voy a hacer la tarta de ananá, y tengo que comprar más harina.

Chile

1. Voy a hacer un pastel de piña, y compraré más harina.

2. Voy a hacer un pastel de piña, y tengo que comprar más harina.

3. Voy a hacer un pastel con piña, y compraré más harina.

Hiszpania

1. Voy a hacer el pastel de piña, y tengo que comprar más harina.

2. Voy a hacer la tarta de piña, y tengo que comprar más harina.

3. Voy a hacer el pastel de piña, y tengo que comprar más harina.

Kolumbia

1. Voy a hacer una torta con piña, y tendré que comprar más harina.

2. Voy a hacer una torta con piña, y tendré que comprar más harina.

3. Voy a hacer una torta de piña. Tengo que comprar más harina.

Meksyk

1. Voy a hacer un pastel con piña, tengo que comprar más harina.

2. Voy a hacer un pastel de piña, tengo que comprar más harina.

3. Voy a hacer un pastel de piña y tengo que comprar más harina.

Wenezuela

1. Voy a hacer una torta de piña, y compraré más harina.

2. Voy a hacer la torta de piña, y tengo que comprar más harina.

3. Voy a hacer una torta de piña, tengo que comprar más harina.

$\mathrm{Z}$ nadesłanych odpowiedzi wydobyliśmy dwie istotne różnice na poziomie leksykalnym. Hiszpańskie słowo pastel ('ciasto') używane było wyłącznie wśród respondentów z Meksyku. Pozostali uczestnicy badania posługiwali się słowami tarta i torta, które do hiszpańszczyzny przeniknęły z języka włoskiego. Pineapple 
natomiast zarówno w Hiszpanii, jak i Ameryce Łacińskiej tłumaczony był jako piña, za wyjątkiem Argentyńczyków, którzy posługują się słowem ananá, opartym na łacińskim ananas, ale zmodyfikowanym pod wpływem wspomnianego języka Avañe’ẽ. Pozostałe różnice obserwowane w tłumaczeniu tego zdania uznać można za błahe; na przykład część respondentów frazę I have to buy ('muszę kupić') przetłumaczyła dosłownie jako tengo que comprar, a część zdecydowała się na użycie czasu przyszłego compraré ('kupię').

Materiał uzyskany z tłumaczeń czwartego zdania prezentuje popularną rozbieżność znaczeniową związaną z czasownikiem coger.

Argentyna

1. Si no agarraré este colectivo, no llegaré a tiempo al comercio, y no podré preparar la cena.

2. Si no agarraré este ómnibus, no llegaré a tiempo al comercio, y no prepararé la cena.

3. Si no tomo este colectivo, no llegaré a tiempo a la tienda, y no podré preparar la cena.

Chile

1. No agarraré el bus, y no llegaré a tiempo al supermercado, y no haré la comida.

2. Si no agarraré el micro, no llegaré a tiempo al supermercado, y no prepararé la comida.

3. Si no agarraré este liebre, no llegaré a tiempo al supermercado, y no prepararé la cena.

Hiszpania

1. Si no cojo este autobús, no llegaré a tiempo a la tienda, y no podré preparar la cena.

2. Si no cogeré este autobús, no llegaré a tiempo a la tienda, y no prepararé la cena.

3. Si no cojo este autubús, no estaré a tiempo en la tienda, y no prepararé la cena.

Kolumbia

1. Si no cojo esta guagua, no llegaré a tiempo al supermercado, y no podré preparar la comida.

2. Si no cojo el colectivo, no llegaré a tiempo a la tienda, y no prepararé la comida.

3. Si no cojo el colectivo, no llegaré a tiempo a la tienda, y no prepararé la comida. 
Meksyk

1. Si no alcanzo este autobús, no estaré a tiempo en el súper, y no podré preparar la cena.

2. Si no alcanzo este camión, no estaré a tiempo en el supermercado, y no podré preparar la cena.

3. Si no alcanzo el camión, no llegaré a tiempo al supermercado, y no prepararé la cena.

\section{Wenezuela}

1. Si no tomo este autobús, no llegaré a tiempo a la tienda, y no prepararé la comida.

2. Si no tomo esta buseta, no estaré a tiempo en el abasto, y no prepararé la comida.

3. Cuando no tomo la buseta, no llegaré a tiempo al abasto, y no podré preparar la comida.

W Hiszpanii czasownik ten znaczy 'chwytać', nie budzi więc wątpliwości konstrukcja coger el autobús. W większości krajów Ameryki Łacińskiej coger jest używany jako wulgarne określenie aktu seksualnego. W związku z tym, ,złapanie" jakiegokolwiek środka transportu w latynoamerykańskiej odmianie języka hiszpańskiego tłumaczy się przy użyciu czasowników agarrar ('łapać, chwytać') i tomar ('brać'). Respondenci z Meksyku wykorzystali w tłumaczeniu czasownik alcanzar ('dosięgnąć/uchwycić'). Różnice na poziomie słownictwa skupiają się wokół leksemów bus, shop oraz dinner. Hiszpanie tłumaczyli je kolejno jako: autobús, tienda i cena. Wyrazy te są znane w latynoamerykańskiej odmianie języka hiszpańskiego, jednak mają w Ameryce Łacińskiej rozmaite synonimy. Począwszy od autobusu, w Argentynie i Kolumbii popularne jest pochodzące z łaciny określenie colectivo, którego znaczenie nawiązuje do zbiorowości (collectivus). Jeden z mieszkańców Argentyny wykorzystał słowo ómnibus, które użytkownikom języka polskiego może wydać się archaiczne, natomiast dla Argentyńczyków jest powszednim określeniem autobusu. W Kolumbii natomiast, podobnie jak w Ameryce Środkowej (między innymi w Portoryko, na Dominikanie oraz na Kubie), pojawia się leksem guagua, który w języku mapudungun ${ }^{16}$ oznacza 'dziecko' prawdopodobnie pod wpływem angielskiego wagon ${ }^{17}$. Chilijczycy posługują się określeniami bus i micro (będącym skrótem od microbús), ale jeden z badanych wykorzystał słowo liebre, oznaczające zająca. W Chile liebre oznacza nie tylko zwierzę, ale również specyficzny rodzaj małogabarytowych autobusów. W Wene-

\footnotetext{
16 Jest to język używany przez członków grupy etnicznej Mapuche, należący do rodziny języków araukańskich, spotykany najczęściej w środkowej części Chile oraz zachodniej Argentynie.

17 Zob. http://etimologias.dechile.net/?guagua (dostęp: 25.01.2021).
} 
zueli taki pojazd nazywa się buseta i ten właśnie rzeczownik podawali w badaniu Wenezuelczycy. Odnośnie do frazy grocery store, wśród użytkowników latynoamerykańskiej odmiany języka hiszpańskiego najczęściej pojawiały się tłumaczenia: tienda, comercio i supermercado (oraz derywat wsteczny súper), których używa się zamiennie w całej Ameryce Łacińskiej. Wyjątkiem jest Wenezuela, gdzie dodatkowo funkcjonuje rzeczownik abasto, pochodzący od czasownika abastar, oznaczającego 'dostarczać', 'zaopatrywać'. Ostatnia z leksykalnych różnic widocznych w tym przykładzie to thumaczenia rzeczownika dinner. Badani z Argentyny, Hiszpanii i Meksyku przekładali go jako cena ('kolacja'). Pozostali respondenci wskazywali na rzeczownik comida, będący synonimem słów 'jedzenie' i 'posiłek'.

Tłumaczenia kolejnego zdania uwydatniły następne różnice w zasobie leksykalnym poszczególnych odmian języka kastylijskiego.

Argentyna

1. Duraznos, plátanos y uvas son costosos.

2. Duraznos, bananas y uvas son costosos.

3. Duraznos, bananas y uvas son costosos.

Chile

1. Duraznos, plátanos y uvas cuestan mucho.

2. Duraznos, guineos y uvas son costosos.

3. Duraznos, guineos y uvas son costosos.

Hiszpania

1. Melocotones, plátanos y uvas son caros.

2. Melocotones, plananos y uvas son caros.

3. Melocotones, bananas y uvas son caros.

Kolumbia

1. Duraznos, bananos y uvas son muy costosos.

2. Duraznos, bananos y uvas son muy costosos.

3. Duraznos, bananos y uvas son muy caros.

Meksyk

1. Duraznos, plátanos y uvas son muy caros.

2. Duraznos, plátanos y uvas son muy caros.

3. Duraznos, plátanos y uvas son muy caros.

Wenezuela

1. Melocotones, bananos y uvas son caros.

2. Melocotones, plátanos y uvas son caros.

3. Melocotones, plátanos y uvas son caros. 
Dla przykładu, zwrot costs a lot tłumaczony był jako caro ('drogi') lub costoso ('kosztowny'). Tylko jeden z respondentów, Chilijczyk, posłużył się kalką costar mucho ('kosztować dużo'), co pozwala przypuszczać, że zwrot ten nie jest powszechnie wykorzystywany przez użytkowników języka hiszpańskiego. Jeśli chodzi o nazwy owoców: peaches, bananas i grapes, tylko ostatnia z nich tłumaczona była we wszystkich przypadkach jednakowo - jako uvas ('winogrona'). Brzoskwinia tłumaczona jest jako melocotón lub durazno. Pierwszy z tych leksemów wywodzi się od łacińskiej nazwy malum cotoneum, oznaczającej owoc pigwy $^{18}$, jednak przez rzymską metodę szczepienia brzoskwiń na odnóżach drzew pigwowych rzeczownik melocotón przyjął się jako określenie brzoskwini. Nazwy tej używa się przede wszystkim w Hiszpanii, jednak jest znana w krajach Ameryki Łacińskiej. Durazno opiera się natomiast na łacińskim leksemie dura ('twarda, szorstka'), co stanowi nawiązanie do specyficznej skórki brzoskwini. Rzeczownik durazno bywa używany w niektórych regionach Hiszpanii, między innymi na Wyspach Kanaryjskich, jednak zdecydowanie częściej spotykany jest w Ameryce Łacińskiej. W przypadku rzeczownika bananas również spotkaliśmy się z kilkoma różnymi tłumaczeniami. Nazwa dominująca w Hiszpanii to plátano, co oznacza zarówno owoc, jak i drzewo bananowca. Etymologia tego określenia sięga greckiego słowa $\pi \lambda \dot{\alpha} \tau \alpha v o \varsigma$ (plátanos), określającego rodzaj rozłożystych drzew $\mathrm{z}$ rodziny platanowatych. Latynoamerykanie używają rzeczownika plátano wymiennie $\mathrm{z}$ banana lub jego odpowiednikiem w rodzaju męskim - banano. Drugi z tych wariantów jest popularny zwłaszcza w centralnej i północnej części Iberoameryki. Respondenci z Chile wskazywali również słowo guineo, które - jako przymiotnik funkcjonujący zamiennie z guineano - określa osobę lub rzecz pochodzącą z Gujany. Guineo jako rzeczownik nazywa niedojrzałe, zielone banany, popularne zwłaszcza w kuchni dominikańskiej i portorykańskiej.

Ostatni z przykładów uwypuklił przede wszystkim różnice w leksyce związanej z zupą.

Argentyna

1. No toques esta olla, está caliente, el hervido no está listo todavía.

2. No toques esta olla, está caliente, la sopa no está lista.

3. ¡No toques esta olla! Está caliente, y la sopa aún no está lista.

Chile

1. No toques esta olla, está caliente, y la sopa no está lista todavía.

2. No toques la olla, está caliente, y la sopa aún no está lista.

3. iNo toques la olla! Está caliente, y la sopa no está lista.

18 Zob. http://etimologias.dechile.net/?melocoto.n (dostęp: 26.01.2021). 
Hiszpania

1. ¡No toques esta olla! Está caliente, y la sopa no está lista todavía.

2. No toques esta olla. Está caliente, y la sopa aún no está lista.

3. No toques esta olla. Está caliente, y la sopa no está lista.

Kolumbia

1. No toques esa olla, está hirviendo, el caldo todavía no está listo.

2. No toques esa olla que está caliente, y la sopa ahora no está lista.

3. No toques la olla que está caliente, y la sopa aún no está lista.

Meksyk

1. No toques esta olla, está caliente, la sopa no está lista todavía.

2. No toques esta olla, está caliente, y la sopa no está lista todavía.

3. No toques la olla que está caliente, la sopa no está lista todavía.

Wenezuela

1. No toques la cacerola que está hirviendo, la sopa no está lista todavía.

2. No toques la olla, está caliente, y el sancocho no está listo todavía.

3. No toques esta cacerola que está caliente, el sancocho aún no está listo.

W Hiszpanii, podobnie jak w większości krajów Ameryki Łacińskiej, słowo soup było tłumaczone jako sopa. Leksem ten hiszpańszczyzna zapożyczyła z germańskiego Suppe. Jeden z argentyńskich respondentów posłużył się słowem hervido, które dosłownie tłumaczy się jako 'wrzątek', jednak w niektórych krajach Iberoameryki jest też ogólnym określeniem płynnej potrawy. Wskazane przez wenezuelskich respondentów słowo sancocho jest nazwą własną kolumbijskiej potrawy na bazie bulionu i - podobnie jak hervido - w części krajów ma charakter uniwersalny. Inne określenie zupy, na które powołali się z kolei probandzi z Kolumbii, to caldo, pochodzące $\mathrm{z}$ łacińskiego caldus ('ciepło'). Leksem pot tłumaczono natomiast jako olla, co jest kalką z łaciny (łac. olla oznacza 'garnek' lub 'słój'). Dwóch badanych z Wenezueli posłużyło się słowem cacerola, które wywodzi się od francuskiego casserole ('rondel'). Główną różnicą pomiędzy olla i cacerola jest rozmiar naczynia - większy w przypadku pierwszego z nich. Można też zauważyć, że w części przykładów yet tłumaczone jest jako aún lub todavía. Oba te słowa są synonimami używanymi zamiennie zarówno w Hiszpanii, jak i w krajach Ameryki Łacińskiej.

\section{Konkluzja}

Powyższe przykłady potwierdzają różnorodność języka hiszpańskiego, spowodowaną najczęściej względami geograficznymi, emigranckimi oraz terytorialno-so- 
cjalnymi. Przeprowadzone przez nas badanie wykazało różnice leksykalne, gramatyczne i socjolingwistyczne między poszczególnymi odmianami. Jak zaznacza José María Tortosa (1986:77), różnice pod względem stopnia industrializacji i zjawisk migracyjnych między regionami pozwalają przypuszczać, że pojawiające się w każdym z nich „konflikty językowe” mają różne podłoże społeczne. $Z$ tego też powodu w jednym miejscu będą innym instrumentem politycznym niż w drugim. „Zrozumienie kwestii językowych w Hiszpanii zakłada zrozumienie różnic gospodarczych, społecznych, kulturowych i politycznych między różnymi regionami kraju. Te różnice są zmiennymi niezależnymi od różnych warunków językowych, ale zarazem te różnorodne warunki językowe są instrumentem i zmienną niezależną od poprzednich". Według badacza przyszłość języków jest kwestią wartości, procesów i problemów wykraczających poza teren ściśle językowy. Różnice i konflikty w obrębie jednego języka wywodzą się z wielu źródeł, implikując między innymi opisane $\mathrm{w}$ artykule zjawiska lingwistyczne i dialekty, przez co jednoznaczne skategoryzowanie problemu jest trudnym zadaniem.

\section{Bibliografia}

GuILleRmo-SAJDAK Marta, 2013, Język hiszpański - język argentyński - język polski. Charakterystyka języka polonijnego używanego w Argentynie, w: Ameryka Łacińska 2 (80), s. 116-133.

HaEnsch Günther, 2002, Español de América y español de Europa (2. a parte), w: Revista de Medicina, Lenguaje y Traducción 7, s. 37-64.

KaGANIEC-KAmIEŃSKa Anna, 2012, Polityka imigracyjna wybranych państw Ameryki Łacińskiej na przełomie XIX i XX wieku, Kraków.

MAGIs Carlos, 1986, Unidad y diversidad del español, w: Zea L. (red.), America Latina y sus ideas, Madrid, s. 467-485.

Real Academia Española, Diccionario de la Lengua Española, edición electrónica, http://www. rae.es.

Rosenblat Angel, 1970, El castellano de España y el castellano de América, Madrid.

SARRAmONE Alberto, 1999, Los abuleos inmigrantes: historia y sociologia de la immigracion argentina, Buenos Aires.

Spina Guillermo, 2011, Historias de inmigrantes italianos en Argentina, Buenos Aires.

SzAŁeK Jerzy, 2013, Neologia we współczesnym języku hiszpańskim, w: Scripta Neophilologica Posnaniensia, t. 3, s. 117-127.

Torres Torres Antonio, 2013, Del Castellano de „Un pequeño rincón” al Español internacional, w: Normas: Revista de Estudios Lingüísticos Hispánicos 3, s. 206-217.

ToRTosa José María, 1986, Polityka językowa a języki mniejszości, Warszawa. 


\section{The diversity of the Spanish language: A comparative study on the material of the Spanish language and its varieties spoken in Latin American countries}

The authors of this article aimed to point out the differences in lexis and grammatical constructions between the varieties of Spanish spoken in Spain and Latin American countries. In order to obtain the most authoritative material the authors used the answers of respondents from six countries: Argentina, Chile, Spain, Colombia, Mexico, and Venezuela. They made this choice because of the mentioned countries' geographical location as well as the anticipated influence of other languages due to migration processes. This allowed the authors to show a lot of variety in the respondents' choice of specific words and sentence constructions. The article also discusses the voseo phenomenon, the rioplatense dialect, and phonetic differences between them. They demonstrated the lexical, grammatical, and sociolinguistic differences between the varieties of Spanish.

Keywords: language diversity, Spanish, Latin America, ethnolinguistics, comparative study. 